\title{
Vegetation composition of old extensive green roofs (from 1980s Germany)
}

\author{
Christine E Thuring* and Nigel Dunnett
}

\begin{abstract}
Introduction: Since their development in the late 1970s in Germany, extensive green roofs (EGR) have become increasingly popular as mitigation tools for urban environmental issues around the world. EGRs are planted with select species, which ensure consistent cover and performance over time. This research presented herein is part of a systematic re-evaluation of EGR technology since the German industry began.

Methods: Given the opportunity to access a small sample of old EGRs installed over 20 years ago in south-west Germany, this research surveyed the vegetation and substrate with an interest in describing these parameters with time-through-space substitution.

Results: Similar to previous studies, this preliminary work found correlations between roof age with vegetation (cover abundance and species diversity) and substrate properties (e.g., depth, organic content, pH, and nutrients). Roof age had positive relationship with soil organic content $\left(C_{\text {org }}\right)$, and negative relationships with substrate depth and soil $\mathrm{pH}$. These soil variables are inter-related, as shallow acidic substrates create unfavourable conditions for decomposition and thereby the accumulation of duff. Substrate variables correlated with EGR vegetation, suggesting a trend of simplified species composition over time. Indeed, $C_{\text {org }}$ had a negative relationship with cover and species diversity of most life forms; only Sedum species had positive associations with $\mathrm{C}_{\text {org }}$.

Conclusions: Considering the dynamics associated with shallow mineral substrates, and the greater floristic diversity of younger roofs, simple Sedum-based vegetation may represent a steady state for conventional EGRs.
\end{abstract}

Keywords: Biodiversity; Extensive green roofs; Germany; Long-term performance; Plant life forms; Sedum; Species diversity; Substrate depth

\section{Introduction}

Growing plants on roofs is an ancient concept common to many cultures and climates. Hanging (or roof) gardens were used by the ancient Greeks as personal sanctuaries to honour the god Adonis, while the Aztecs used them for urban agriculture and amenity (Arhendt, 2007). Grass (or sod) roofs have a long and global lineage, too, often for areas lacking building materials yet requiring insulation from exposure and extreme climates (e.g., Scandinavia, sub-Saharan Africa, American Midwest) (Adler, 2005; Arhendt, 2007; Grant, 2006). Grass roofs are often colonised by spontaneous vegetation that closely represents the flora of the region. In the late 18th to mid-19th centuries, tar-paper-gravel (TPG) roofs became popular in

\footnotetext{
* Correspondence: c.thuring@sheffield.ac.uk

Department of Landscape, Floor 9, The Arts Tower, Western Bank, Sheffield, South Yorkshire S10 2TN, UK
}

many German cities (e.g., Berlin, Göttingen, Osnabrück, Karlsruhe) to stop the spread of fire and provide insulation (Köhler and Poll, 2010). TPG roofs were standardised per city: Göttingen TPGs had $50 \mathrm{~mm}$ (each) of sand and gravel (Bornkamm, 1961), while Berlin TPGs comprised a thin layer of sand topped by $100-150 \mathrm{~mm}$ of gravel with loam (Darius and Drepper, 1983). The vegetation that colonised these early systems and/or which developed following sowings in the 1980s, range from xeric Sedo-Scleranthetea communities on shallow depths to grassy Festuco-Brometea communities on deeper substrates (Bornkamm, 1961; Bossler and Suszka, 1988; Buttschardt, 2001; Poll, 2008).

Today's modern extensive green roofs (EGRs) differ from these predecessors in that they are thin, lightweight systems designed as socio-environmental solutions for the urban environment (Krupka, 1992). Developed in Germany,

\section{Springer}

(c) 2014 Thuring and Dunnett; licensee Springer. This is an open access article distributed under the terms of the Creative Commons Attribution License (http://creativecommons.org/licenses/by/2.0), which permits unrestricted use, distribution, and reproduction in any medium, provided the original work is properly cited. 
EGRs emerged in the 1970s as part of that era's greater Green Movement, which also included materialization of the Green Party, Greenpeace, etc. (Galtung, 1986). In the spirit of the times, vegetated roofs were also seen as opportunities to reconnect urban dwellers with nature (Minke and Witter, 1983). Due to constraints imposed by roof loading and low maintenance requirements, EGRs stand apart from earlier green roof types by their system build-ups (Figure 1) which balance environmental function and performance with a standardised and economically sustainable green roof market.

In the meantime, Earth's human population continues to grow (UNFPA, 2011) while becoming increasingly urbanised (UNFPA, 2007). Along with other forms of green infrastructure, green roofs are recognised as valuable technologies for alleviating the environmental impacts of urbanisation and restoring ecosystem services, which include potable water, clean air, crop pollination, and social well-being, among others (CBD, 2012; Millennium Ecosystem Assessment, 2005a). Because of their capacity to support biodiversity, which is the keystone of ecosystem services (Millennium Ecosystem Assessment, 2005b), green roofs can contribute to a healthy, resilient, and equitable future. Concurrently, green roof markets continue to grow in Germany (FBB, 2012) and in other parts of the world [e.g., Peck, 2012].

Modern EGRs comprise at least two layers - vegetation and growing substrate - but usually multiple layers are used (e.g., root barrier, protection mat, drainage layer). By definition, extensive systems are shallower than $200 \mathrm{~mm}$ while intensive roofs (or roof gardens) are deeper (FLL, 2008). Table 1 summarises the types of vegetation for the range of EGR depths. Being intended for amenity, intensive green roofs have higher loading capacities than EGRs, and their deeper depths permit larger plants and more species, not to mention park-like features such as ponds and benches (Osmundson, 1999; Weiler and Scholz-Barth, 2009). Due to issues associated with poor drainage, single-layer systems should be limited to roofs with a minimum $2 \%$ slope (Krupka, 2006). On multiplelayer systems, the drainage layer is designed to move excess water towards roof drains in order to minimise water logging and hydrostatic load (Kolb and Schwarz, 1999). Theoretically, drainage layers with storage cups can provide moisture to plants during periods of drought but, unless the cups are filled with granular infill, the substrate is effectively separated from the stored water by an air gap, which prevents capillary action. Therefore, the only way by which plants can access such moisture is through evaporation from the stored water into the substrate (Vesuviano, 2013).

The first guidelines for the planning, construction, and maintenance of green roof systems were published in 1982 by the German Landscape Development and Landscaping Research Society, or the FLL (Forschungsgesellschaft Landschaftsentwicklung Landschaftsbau, 2008). These technical standards have been essential to the development and sustained growth of the German green roof industry and market (Ansel et al., 2011).

For EGR plant selection, early green roof pioneers took ecological reference from climax and sub-climax plant communities that occur in environmental conditions analogous to those of roofs (e.g., montane, dry grasslands). Hardy and drought-tolerant taxa, including

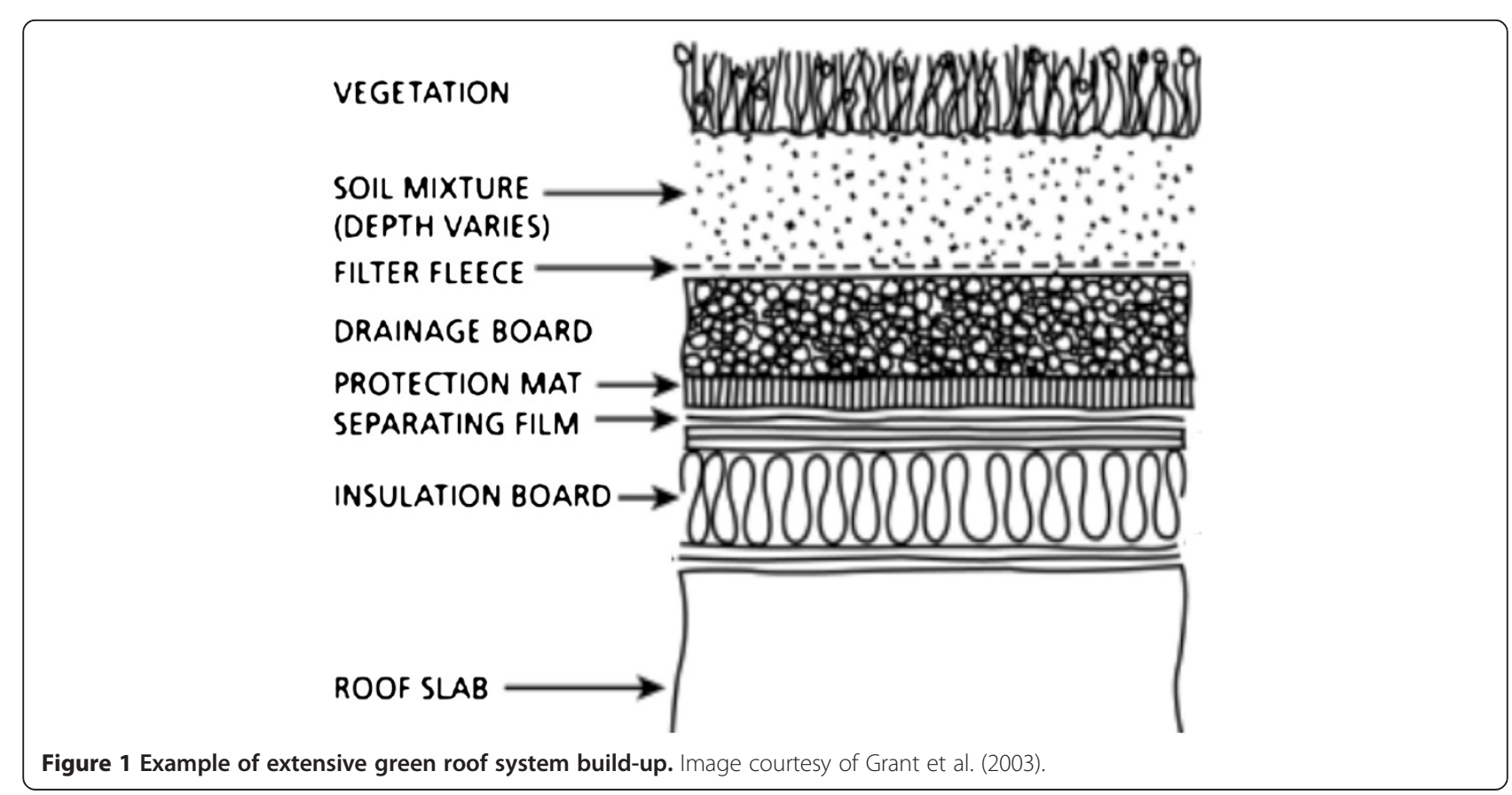


Table 1 Different depths support different vegetation forms

\begin{tabular}{ll}
\hline Depth $(\mathbf{m m})$ & Vegetation form \\
\hline $40-100$ & Moss, sedum \\
\hline $50-110$ & Sedum, moss, herbaceous \\
\hline $100-180$ & Sedum, herbaceous \\
\hline $150-250$ & Grass, herbaceous \\
\hline Adapted from FLL $(2008$, p. 43). &
\end{tabular}

native and non-native species as well as ornamental cultivars that are suited to extreme exposures were trialled and tested, and now serve as the foundation of many EGR species lists (Kolb et al., 1983; Kolb and Schwarz, 1999). One exceptionally well-suited plant community, the Sedo-Scleranthetea, is defined by poor grassland consisting primarily of low-growing herbs, short-culmed and thin-leaved grasses, mosses and lichens (Ellenberg, 1986). The herbs are represented predominantly by succulents, in particular Sedum species and winter annuals, which explains why Sedum species have become synonymous with EGRs.

EGR substrates are $70 \%$ to $90 \%$ mineral (by volume) (Kolb and Schwarz, 1999), and engineered 'soil-less' media are commonly used for rooftop applications for a variety of reasons. For one, the high porosity of mineral substrate promotes excellent drainage and oxygenation for the root environment, but also holds sufficient water to support plant growth between rain events (Handreck and Black, 2010). Furthermore, mineral aggregates resist compression and shrinkage, thereby maintaining medium structure and further promoting drainage and aeration (Dunnett and Kingsbury, 2004). It is important to recall that these standards were developed in the continental climate of central Europe, and that EGRs in other climates often require different criteria [e.g., Williams et al., 2010].

The amount of rainfall retained by green roofs is of particular interest to cities with aging stormwater infrastructure because of their function of retaining and detaining runoff. Depth strongly influences substrate stormwater performance, as deeper substrates have greater storage capacity (Mentens et al., 2006; VanWoert et al., 2005). In spite of their shallow substrates $(<150 \mathrm{~mm})$, EGRs have measured cumulative annual retentions of $70 \%$ in northern Germany (Liesecke, 1995), 60\% in North Carolina (Moran et al., 2004), and 50\% in northern England (Stovin et al., 2012). In addition to depth, retention values depend on the intensity and duration of a rain event, local climate, vegetation, and roof slope (DeNardo et al., 2005; Dunnett et al., 2008b; VanWoert et al., 2005; Villarreal and Bengtsson, 2005; Yio et al., 2013). Most hydrologic models are based on relatively young green roofs or test facilities and, other than one company's proprietary research station (Uhl et al., 2003), the evaluation of green roof hydrological performance over time is largely unknown.

In addition to their benefits of mitigating stormwater runoff, EGRs are promoted in many cities around for the world for improving air quality (Speak et al., 2012), reducing the urban heat island (Dimoudi and Nikolopoulou, 2003; Takebayashi and Moriyama, 2007; Wong et al., 2003), improving thermal insulation (Simmons et al., 2008), mitigating low frequency noise (Connelly and Hodgson, 2013), supplementing urban green infrastructure (Grant, 2012), enhancing urban biodiversity (Brenneisen, 2006; Gedge and Kadas, 2004; Grant et al., 2003) and much more (Francis and Lorimer, 2011; Oberndorfer et al., 2007).

Ecological designs, particularly through manipulations of the substrate, can transform EGRs from technical systems into heterogeneous ecosystems. Deeper depths offer more diverse vegetation that can in turn provide valuable foraging resources for urban bees (Tonietto et al., 2011). Diversifying substrate materials and creating mounds can offer refuge to invertebrates from extreme temperatures (Buttschardt, 2001). Such variations of microhabitat correlate with invertebrate species richness (e.g., spiders, beetles) (Brenneisen, 2003; Kadas, 2011; Mann, 1996). In Basel, Brenneisen (2009) showed that structurally diverse substrates and a stable mosaic of gaps in the vegetation will allow rare, even extirpated, invertebrates to colonise shallow EGRs, although this has yet to be tested and achieved in other places. The provision of habitat resources, like perches and food and water supply, can accommodate the breeding needs of ground-nesting birds (Baumann, 2006; Fernandez-Canero and Gonzalez-Redondo, 2010).

A small body of plant community ecology studies has applied phytosociological methods to green roofs in the attempt of classifying the vegetation into plant communities. The vegetation of old TPG roofs approximates the composition of some natural plant communities, and supports a novel plant community, the Poetum anceptiscompressae (Typical Poa meadow) (Bornkamm, 1961; Bossler and Suszka, 1987; Buttschardt, 2001; Darius and Drepper, 1983; Poll, 2008). Although it approximates the Sedo-Scleranthetea, EGR vegetation does not classify satisfactorily into plant communities mainly because of introduced species and deficient seed rain (Buttschardt, 2001; Poll, 2008).

Other than the ecological research mentioned above, most green roof research is engineering- or horticultureoriented with the goal of understanding performance and function under different conditions (Blank et al., 2013). The requirements of experimental controls and replication mean that green roof research is usually conducted on mock-ups or platforms (Dvorak and Volder, 2010). If actual green roofs are studied, they are rarely older than 10 years and the timeframe for most green 
roof successional research is relatively short [e.g., Bates et al., 2013; Rowe et al., 2012]. However rare, long-term observations of ecological phenomena and the consistent and reliable accumulation of long-term synoptic datasets are essential to understanding how natural systems work (Callahan, 1984; Franklin et al., 1990; Likens, 1989). In any case, the study of EGRs as ecosystems subject to the laws and processes of nature, as defined by ecological theories and principles, has hardly been touched upon (Cook-Patton and Bauerle, 2012).

If EGRs can serve as green infrastructure solutions for an increasingly urbanising planet (Grant, 2012; Millennium Ecosystem Assessment, 2005a), then understanding their long-term performance is crucial. Furthermore, understanding the factors which affect species richness on EGRs over time can help towards more informed designs and specifications for biodiversity in the urban context. This research surveyed the vegetation and substrate on some of the oldest EGRs in south-west Germany and bolsters its limited sample size with the Buttschardt (2001) dataset, which had been analysed differently. Based on the species poverty of TPG roofs, we hypothesised that floristic diversity on EGRs also becomes more homogenous over time. With reference to competition theory and other green roof research, we hypothesised that very shallow substrate depths $(\leq 80 \mathrm{~mm})$ would provide higher species diversity compared with deeper depths $(\geq 100 \mathrm{~mm})$.

\section{Methods}

The development of vegetation on EGRs has been conjecture at best due to issues such as accessibility and deficient scientific method. An EU-funded IndustryAcademia Partnership (Marie Curie IAPP) helped to close this gap (Green Roof Systems Project, 2013). One of the earliest EGR system manufacturers, the industry partner (ZinCo $\mathrm{GmbH}$ ) helped gain access to six of its oldest EGRs (Roofs 1-6). Three non-ZinCo roofs were included, as well. The sampling region was confined to the Stuttgart region (south-west Germany), which is typified by a continental climate.
Nine EGRs were surveyed over the course of two growing seasons (2010 and 2011) (Table 2). Several roofs feature prototypic EGR systems and/or materials, some of which have become commonplace to the green roof industry while others have not been taken up. Two of the pitched roofs (Roofs 2 and 4), for example, were custom built because such greening had not been done before, while the pre-grown Styrofoam modules on Roofs 5 and 6 did not last long on the German market. In spite of the differences in location, age, area and slope, the roofs are all based by typical EGR substrates (e.g., mineral: organic ratio), and field observations confirmed the use of multiplelayered systems.

Although initial data was not available, the roofs surveyed were all built in the early years of the German green roof industry and would have adhered to the early FLL standards. Verbal information suggests that all roofs were regularly maintained in their early years, which would have included weeding and possibly mowing and fertilising. According to personal correspondence with roof contacts, maintenance contracts were not renewed in the early 1990s, which means that the roofs had not been maintained in about 10 years at the time of survey.

Little written baseline information was available for the roofs surveyed. Since German companies/institutions typically purge any documentation over 10 years old, only sites with staff members interested in the green roofs had retained any related documents (Roofs 1, 4, 9). Some roofs had technical drawings that included reference to species lists and substrate depths (Roofs $2,7,8$ ). Unfortunately, original substrate depth, details of substrate composition and species lists cannot be known for certain. That being said, since the roofs were built in the time of the FLL guidelines, they likely adhered to those specifications, meaning that soil $\mathrm{pH}$ was between 6.5 and 8.0, soil organic content below $65 \mathrm{~g} / \mathrm{L}$, and substrate depth less than $200 \mathrm{~mm}$ (FLL, 2008). These results mainly present a descriptive snapshot of what is present today.

Table 2 Summary of the nine extensive green roofs in order of age at time surveyed

\begin{tabular}{|c|c|c|c|c|c|c|c|}
\hline Roof \# & Roof name & Age at survey & Year installed & Area $\left(\mathrm{m}^{2}\right)$ & Slope $\left({ }^{\circ}\right)$ & \# quadrats & \# species \\
\hline 1 & FH Nürtingen & 23 & 1987 & 258 & 0 & 12 & 32 \\
\hline 2 & Römermuseum, Köngen & 23 & 1987 & 350 & 17 & 18 & 9 \\
\hline 3 & Pliensaufriedhof, Esslingen & 33 & 1977 & 500 & 0 & 15 & 11 \\
\hline 4 & Gärtnereihof Tübingen & 24 & 1986 & 2,160 & 15 & 16 & 21 \\
\hline 5 & Verkehrsbetrieb Area 1 & 25 & 1986 & 1,860 & 0 & 14 & 21 \\
\hline 6 & Verkehrsbetrieb Area 2 & 25 & 1986 & 2,064 & 0 & 14 & 21 \\
\hline 7 & Stuttgart Rathausgaragedach, PV & 21 & 1990 & 1,300 & 0 & 15 & 26 \\
\hline 8 & Stuttgart Rathausgaragedach, low & 21 & 1990 & 1,000 & 0 & 14 & 30 \\
\hline 9 & Killesberg Dach & 20 & 1991 & 450 & 30 & 18 & 23 \\
\hline
\end{tabular}




\section{Data collection}

The traditional tool of quantitative plant ecology, a $1-\mathrm{m}^{2}$ quadrat (Braun-Blanquet, 1932; Mueller-Dombois and Ellenberg, 1974), was used for floristic description, specifically for cover abundance records. With the goal of describing EGR vegetation, primary survey methods with ecological objectives were deemed appropriate for including the diversity of roof constructions since the intent was to correlate local variation in vegetation composition with variation in environmental factors (van der Maarel, 2005). Floristic sampling occurred from early June to mid-July and substrate and biomass harvest in autumn. Each roof was sampled once and is represented by between 12 and 18 quadrats; this number depended on the type of roof, its surface area, and the vegetation.

Quadrat placement was determined by site conditions, vegetation homogeneity, environmental gradients, and the statistical requirements of sampling (Kent and Coker, 1994). A small roof with uniform vegetation (Roof 1) was sampled by systematically locating points at regular intervals, for example, while roofs with heterogeneous vegetation were sampled using stratified methods that clustered major sources of variation. In those cases, stratified methods first defined physiognomic groups (e.g., Sedum cover versus shrubby mounds) and then sampled the predominant, homogeneous vegetation (Roofs 3, 5-8).

Similarly, pitched roofs (Roofs 2, 4, 9) were sampled using systematic transects, which permit the description of maximum variation across an environmental gradient over the shortest distance (Kent and Coker, 1994). The diversity of roof constructions from this primary survey was united for analysis because of the limited sample size but also through reference to the methodological approach of Buttschardt (2001), whose surveys included two pitched roofs in a sample of less than ten EGRs.

Above-ground cover abundance by plant species was measured at percent cover (\%) per $\mathrm{m}^{2}$ for individual species and also by amalgamated physiognomic life form groups (Table 3). Although they qualify as forbs, succulents (e.g., Sedum species) were separated into their own group because of their unique structures and strategies. See Additional file 1 for the full species list and species

Table 3 Species were grouped into physiognomic life form groups

\begin{tabular}{ll}
\hline Life form & Vegetation type \\
\hline Woody & Trees, shrubs, sub-shrubs \\
\hline Grasses & Grasses \\
\hline Succulents & Succulent and crassulacean species \\
\hline Forb & Herbaceous flowering plants \\
\hline Bulb & Bulbous flowering plants \\
\hline Cryptogam & Mosses and liverworts \\
\hline
\end{tabular}

frequency on the nine roofs. Certainly, grouping species has the drawback of masking the variation of ecological strategy within each group, but it can also reveal important environmental factors influencing the structure of the vegetation. Likewise, treating large numbers of species individually can hinder the analysis and interpretation of the broader functional aspects of the vegetation (van der Maarel, 2005).

Each sampling plot received a record for substrate depth, taken as the mean of three measurements per quadrat. Depth measurements typically ranged from the substrate surface to the filter sheet separating substrate from the drainage layer below. Taken together, each roof therefore received a mean value for substrate depth. Interestingly, in spite of the different forces one would expect, substrate depth on pitched versus flat roofs was similar for both the mean and the measured range across each roof (data not shown); of course, the absence of original data prevents any meaningful conclusions. Overall, we would expect pitched roofs to have deeper depths at the base of the slope and shallower depths at the top, supporting an accordingly stratified vegetation (Table 1).

Finally, excepting the Killesberg site, eight roofs were sampled for physical and chemical substrate properties using a $(10 \mathrm{~cm})$ soil corer (Firma Schwab, Waidhofen). One or two cores were taken per quadrat, all vegetation removed, and core profiles photographed before being united into a single, $20 \mathrm{~L}$ sample $(15 \mathrm{~L}$ are required for analysis, plus $5 \mathrm{~L}$ retain sample). Cored gaps were re-filled with a commercially available green roof substrate, 'Steinrosenflur'. The University of Hohenheim LA-Chemistry Laboratory conducted soil analyses in adherence with the FLL guidelines.

\section{Data analysis}

The information used for analysis here includes cover abundance (\%) of life form groups as well as species diversity; roof age (age at time of survey); soil depth (mm); soil nutrients (nitrogen, phosphorus, potassium and magnesium) (as measured in $\mathrm{mg} / \mathrm{L}$ ); soil organic content $(\mathrm{g} / \mathrm{L})$; and soil $\mathrm{pH}$ (as measured by $\mathrm{CaCl}_{2}$ ). As a first step, the relationships between these multiple variables are investigated using Spearman's Rank Order Correlation (rho), which can describe the strength and direction of relationships. This non-parametric solution was chosen because some of the data was ordinal and most of it was not normally distributed. Preliminary tests were performed to ensure no violation of the assumptions of normality, linearity and homoscedasticity.

\section{Results and discussion}

Given the small sample size and the lack or incomplete quality of original documentation, we can only speculate 
about how the vegetation and substrate properties develop on EGRs over time. In the results that follow, it is important to note that the context of causation and interlinkage amongst variables is inadequately known; there may be spurious correlations or significant relationships that are influenced more by lurking variables rather than the two variables identified. To address the possibility of spurious correlations, the results and discussion may serve for consideration of the scenarios suggested but shall not be treated as conclusions. Since soil properties fundamentally determine how vegetation will grow, substrate effects shall be discussed first.

\section{Roof age and soil properties}

The older EGRs had lower soil $\mathrm{pH}$ and less substrate depth, less biomass, and greater soil organic content than younger roofs. Some of these effects are clearly related and do not require elaboration (e.g., less soil depth $=$ less biomass), while others are of particular relevance to longterm green roof performance.

\section{Decreased soil pH over time}

Although not significant, the roofs surveyed in this study concur with findings from others in suggesting that soil $\mathrm{pH}$ declines over time. Of the eight roofs sampled for soil, $\mathrm{pH}$ values ranged from 5.2 to 7.2. Only the two youngest roofs fell within the recommended range of 6.5 to 8.0 [according to FLL (2008)]. A similar study in Karlsruhe, of EGRs between 3-8 years old at time of survey (installed between 1992-1997), recorded soil $\mathrm{pH}$ values between 5.8 and 7.6, of which two (7 years old) fell below the FLL standard (Buttschardt, 2001). Of 10 EGRs sampled in Hannover, Schrader and Boening (2006) also found that $\mathrm{pH}$ values for the older roofs all fell below the FLL recommendation. In any case, soil $\mathrm{pH}$ was lower on the older EGRs (8-12 years old at time of survey; installed 1990-1994) compared to the younger roofs (3-4 years old; installed 1998-1999). Köhler and Poll (2010) observed differently in Berlin because EGRs there were systematically amended with lime as a response to acid rain in the 1980s.

In fact, a number of controlled studies have noted significant declines in soil pH of EGR substrates over time. In a systematic test of 23 mineral substrates (no organic matter), Jauch and Fischer (2000) found that all trended towards acidification over the 7-year study period. Lava substrates fell from between $\mathrm{pH} 7.5$ and 8.2 (in 1993) to 5.7 and 6.2 (by 2000); expanded clays from between pH 6.7 and 9.6 (1993) to 5.1 and 6.0 (2000); and expanded shale from between pH 8.1 and 9.0 (1993) to 4.8 and 6.3 (2000). The most stable substrates tested were those composed of brick, with $\mathrm{pH}$ values declining from between 7.0 and 9.0 (1993) to 5.8 and 7.7 (2000). Another study of twelve substrates over a period of up to 16 years, which included the same aggregates described above plus others, noted that $\mathrm{pH}$ drops significantly in the first years after installation (Liesecke, 2006). The apparent drop in $\mathrm{pH}$ suggests that the materials comprising EGR substrates lack sufficient buffering capacity. These effects are discussed in detail further on.

\section{Less depth over time}

A preliminary correlation analysis suggests that substrate on older EGRs was significantly shallower than on the younger roofs surveyed ( $r h o=-0.481, P<0.000, \mathrm{n}=134$ ). Since EGRs are relatively shallow to begin with, and given the lack of long-term performance research on these systems, such a phenomenon would have great consequences for emerging markets that employ minimal FLL guidelines because regionally tested standards have not yet been developed (Snodgrass and McIntyre, 2010). Recalling the caution of spurious relationships as expressed above, and the limitations of sample size in this study, this effect nevertheless deserves careful consideration.

Table 4 shows the surveyed EGRs arranged by ordinal age groupings of mean depth $(\mathrm{mm})$ per roof. These values, illustrated in Figure 2, suggest a linear decrease in mean substrate depth over time. If the data point from the oldest roof surveyed (Pliensaufriedhof) is considered an outlier, a negative trend becomes clearer. That roof supports dense Sedum cover that is typical EGR vegetation, but it was originally installed as a semiintensive system (in 1978) and would have received more substrate than its younger counterparts.

A Kruskall-Wallis test revealed a statistically significant difference in substrate depth across the four age groupings (depth $1, \mathrm{n}=46$ : $20-21$ years; depth $2, \mathrm{n}=29$ : 22-23 years; depth $3, \mathrm{n}=44: 24-25$ years; depth $4, \mathrm{n}=$ 15: $>26$ years $\left.), \chi^{2}(3, \mathrm{n}=134)=42.74, P<0.01\right)$. The two oldest roof age categories had small means $(39.7 \mathrm{~mm}$, $53.3 \mathrm{~mm}$, respectively), especially by contrast with the younger age groups, which had mean depths greater than $86 \mathrm{~mm}$. In spite of the small sample size, and the variability amongst roofs, these results strongly suggest that EGR substrate depth decreases over time, although it is unclear how or when this would occur.

Both the FLL standards and industry practice in Germany are designed to rule out compaction from point of installation. First, the DIN 18127 laboratory standard (Proctor Test) for substrate manufacture ensures that a substrate has already factored compression into its ordered volume. Further, in the case of EGR substrates delivered by silo trucks (which compromise particle size distribution due to shattering) (Roth-Kleyer, 2006), the FLL (2008) recommends maintaining the prescribed granulometric distributions by including greater proportions of large particles into those blends. In addition 
Table 4 Mean substrate depth on nine extensive green roofs in order of increasing roof age

\begin{tabular}{|c|c|c|c|}
\hline Roof age grouping & Roof \# & Roof name (in order of age at time of survey) & Mean substrate depth $(\mathrm{mm})$ \\
\hline \multirow[t]{3}{*}{$20-21$} & 7 & S-Rathausgaragedach, PV & 75.4 \\
\hline & 8 & S-Rathausgaragedach, low & 69.8 \\
\hline & 9 & Killesberg Dach & 84.7 \\
\hline \multirow[t]{2}{*}{$22-23$} & 1 & FH Nürtingen & 72.3 \\
\hline & 2 & Römermuseum, Köngen & 76.6 \\
\hline \multirow[t]{3}{*}{$24-25$} & 4 & Gärtnereihof Tübingen & 61.5 \\
\hline & 5 & Verkehrsbetrieb Area 1 & 52.8 \\
\hline & 6 & Verkehrsbetrieb Area 2 & 58.1 \\
\hline$>26 y r$ & 3 & Pliensaufriedhof, Esslingen & 61.6 \\
\hline
\end{tabular}

to the FLL, EGR system and/or substrate providers will often calculate substrate volume for installation using 'settlement factors' of between 1.1 and 1.25, depending on the substrate (e.g., ZinCo GmbH, 2013, p. 15).

Although most of these roofs were installed in the early days of the EGR industry, they may still be considered representative of conventional German EGRs. The oldest roof sampled (Roof 3, Pliensaufriedhof) preceded the first FLL guidelines by four years, but it features a system build-up that remains commonplace to the industry so would presumably embody certain standards. The roofs surveyed would not have been installed using silo trucks, either, which only became prevalent after the industry had developed sufficiently; by 2002, 70\% of EGR installations in Germany used blower trucks (Roth-Kleyer, 2002).

Substrate depth fundamentally affects EGR vegetation, whether in terms of establishment and growth (Durhman et al., 2007; Getter and Rowe, 2009; Rowe et al., 2012;
Thuring et al., 2010), species dominance and cover diversity (Dunnett et al., 2008b; Emilsson and Rolf, 2005; Nagase and Dunnett, 2010), or survival across challenging seasons (Boivin et al., 2001; Getter and Rowe, 2007). Shallower depths also inhibit the growth of taller vegetation (Table 1) which together compromise hydrological performance (Dunnett et al., 2008a) and other benefits like the cooling of buildings in hot seasons (Sailor, 2008; Santamouris et al., 2007).

\section{More soil organic content over time}

The older roofs surveyed typically had more soil organic content $\left(\mathrm{C}_{\text {org }}\right)$ than younger roofs. With reference to the FLL specification that $\mathrm{C}_{\text {org }}$ should be no higher than $65 \mathrm{~g} / \mathrm{L}$, four of the eight roofs were in excess (FH Nürtingen: $72 \mathrm{~g} / \mathrm{L}$; Pliensaufriedhof: $189 \mathrm{~g} / \mathrm{L}$; Köngen: $126 \mathrm{~g} / \mathrm{L}$; Tübingen: $79 \mathrm{~g} / \mathrm{L}$ ), two were close to the limit (Verkehrsbetrieb A1: 60 g/L; Rathausgarage lower: $61 \mathrm{~g} / \mathrm{L}$ ) and two were acceptable (Verkehrsbetrieb A2: $25 \mathrm{~g} / \mathrm{L}$;

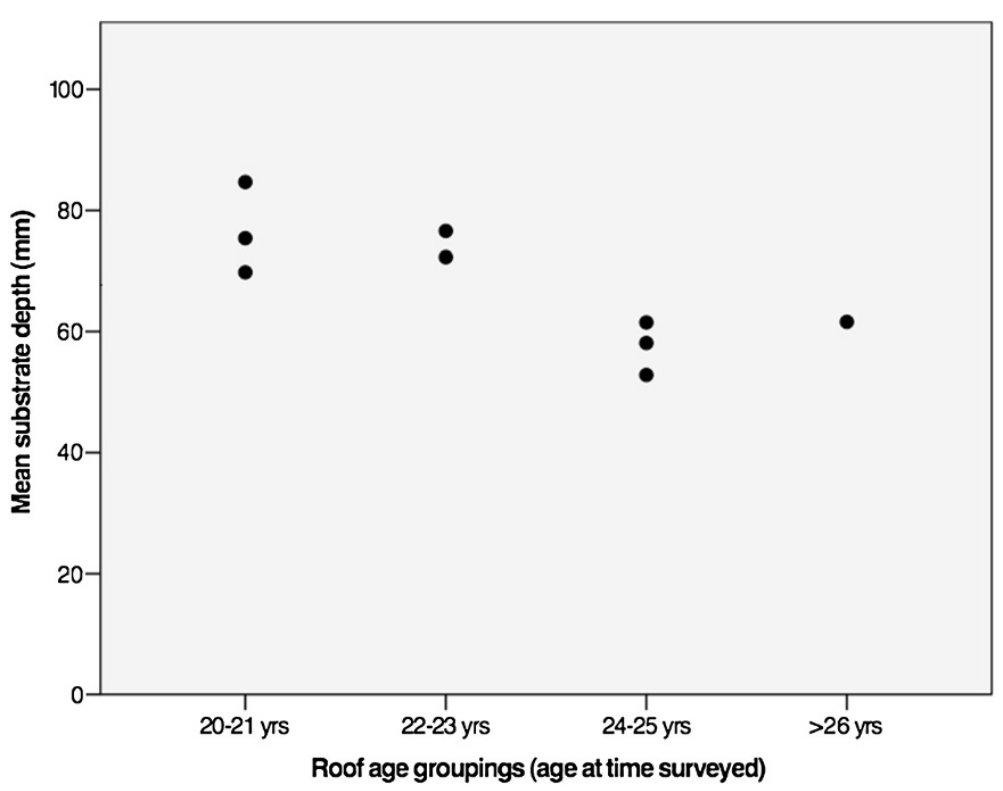

Figure 2 Mean substrate depth decreases on extensive green roofs over time. 
Rathausgarage PV: $49 \mathrm{~g} / \mathrm{L}$ ). As mentioned above, the roofs sampled probably adhered to the FLL guidelines and the same would apply to substrate composition. Vegetation surveys of EGRs in Karlsruhe recorded 'high to very high' $\mathrm{C}_{\text {org }}$ of which measured values did not differ significantly from those of old, spontaneously vegetated TPG roofs (Buttschardt, 2001). Köhler and Poll (2010) in Berlin similarly observed that $\mathrm{C}_{\text {org }}$ on 20-year-old EGRs was not significantly different from 100-year-old TPGs.

Organic content in EGR substrates is specified to be low because organics retain moisture better than mineral substances (influencing roof loads), while oxidation, compression and other forms of weathering limit their longevity (Kolb et al., 1983). Similar to 'soil-less' potting media, mineral-rich EGR substrates are designed to provide comparable moisture holding properties to organicrich mixes through specific particle size distributions (FLL, 2008; Miller, 2003). The limited nutrient content of high-mineral EGR substrates gives the desired green roof vegetation a competitive edge over ruderal volunteer species, which typically require more fertile soils (Kolb and Schwarz, 1999). Nutrient-holding capacity is an important consideration for organic material on EGRs, too, particularly with respect to runoff quality and surface water pollution (Emilsson and Rolf, 2005).

In their study of carbon sequestration on twelve Sedum-based EGRs (ranging from 1 to 6 years in age and 2.5 to $12.7 \mathrm{~cm}$ in depth), Getter et al. (2009) found that the three shallowest roofs $(2.5 \mathrm{~cm})$ increased in soil carbon with respect to age. Their parallel, plot-based study $(6 \mathrm{~cm})$ found that $100 \mathrm{~g} \mathrm{C}^{*} \mathrm{~m}^{-2}$ was sequestered by the substrate over two growing seasons. Liesecke (2006) similarly observed, in twelve roofs sampled in northern Germany, that the four single-layer EGRs with expanded shale $(5,8,11,14 \mathrm{~cm})$ had the highest $\mathrm{C}_{\text {org }}$ and thickest duff layer after 12 years. Of those, the shallowest depths had the highest $C_{\text {org }}$ values. By contrast, the multiplelayered systems decreased in $\mathrm{C}_{\text {org }}$ content. These results infer that decomposition by microbial activity is inhibited on shallow, mineral-rich EGRs, hence the accumulation of organic material in the form of thatch or duff. Liesecke (2006) also reported that the same four roofs had the highest values for water holding capacity and exceeded to nearly twice their specified loading weight. While beneficial for stormwater retention, this development can have serious repercussions if the roof structure is not designed for such loads. It is worth noting that single-layer EGR systems declined in popularity in Germany since that study.

A couple studies report that $C_{\text {org }}$ on EGRs sinks in the early years after installation and then increase after 10 years, and that soil formation, or pedogenesis, begins to occur after 20 years (Köhler and Poll, 2010; Schrader and Boening, 2006). Although one might expect a build- up of 'nutrient capital', the accumulation of organic matter in soil can actually lead to a decrease in nutrient availability over time (Hodgson, 1990). In semi-natural grasslands, the accumulation of dead plant material over the course of natural succession on nutrient-poor mineral substrates can lead to 'dramatic changes' in the soil (Berendse, 1998, p. 85). The increase in soil organic matter can set off a series of further developments in the soil, including increased nitrogen mineralisation (by a factor of 10 to 20 over as little as 50 years), increased soil moisture content, as well as a strong decline in soil $\mathrm{pH}$ and soil $\mathrm{Ca}^{2+}$ content (ibid).

Decreasing soil $\mathrm{pH}$, as suggested by this and other studies, can also lead to an accumulation of $\mathrm{C}_{\text {org }}$ because of the effects of $\mathrm{pH}$ on microbial activity, which are essential to nutrient cycling and decomposition, as well as plant nutrient uptake (Berendse, 1998). Beneficial microorganisms have preferred $\mathrm{pH}$ ranges in which they function best: Rhizobium bacteria prefer $>5$; ectomycorrhizal fungi prefer 4 to 6 (some 7); endomycorrhizal fungi prefer 4.5 to 8 ; bacteria that convert ammonium to nitrate prefer $>6$; and bacteria that attack fungi prefer 6.5 to 7.5 (Handreck and Black, 2010). Roof exposure, substrate depth, and distance to nearest green space are the main limitations to colonisation of EGRs by soil fauna, which are limited to xero- and thermophilic pioneer species (Schrader and Boening, 2006).

Likewise, sufficient nutrient provision and strong plant growth combined with incomplete litter decomposition inevitably leads to humus accumulation. However, EGR substrates can only offer limited plant nutrition due to their high water permeability and shallow depths, not to mention low cation exchange capacity (Emilsson et al., 2007). Since mineralised nutrients are rapidly leached out of EGR systems (ibid), the application of slowrelease fertiliser is part of the EGR maintenance protocol (FLL, 2008). Several studies propose that ecosystem services by green roofs can be enhanced by providing the conditions for diverse and persistent communities on EGRs - whether plant species and functional groups (Lundholm et al., 2010) or soil biota, like invertebrates (Kadas, 2011) and fungi (McGuire et al., 2013).

\section{Roof age and vegetation development}

Some life forms are more interesting than others to this study. Grasses and forbs, for example, are of interest because they represent great potential for floristic diversity and thereby more complex opportunities for food webs and the habitat needs of animals and insects (Baumann, 2006; Kadas, 2011; Mann, 1996). Succulents are interesting because they are popular on species lists around the world (Snodgrass and Snodgrass, 2006). The most prevalent genus, Sedum, can typically tolerate extreme conditions yet perform well in favourable conditions, while also 
creating reliable roof vegetation cover, which absorbs moisture, prevents erosion, inhibits colonisation, and requires hardly any maintenance (Kolb and Schwarz, 1999). While we cannot know how plant cover has changed over time, succulents certainly had the most consistent cover of all the life forms surveyed here, whether as dominant species or as constant groundcover beneath taller herbs and grasses (data not shown).

\section{EGR floristics most influenced by $\mathrm{C}_{\text {org }}$ and phosphorus}

Cover and species diversity of all life forms were most strongly affected by substrate properties. $\mathrm{C}_{\text {org }}$ had negative relationships with cover abundance and species diversity for all life forms except succulent cover which had a positive relationship. Soil phosphorus had similar effects as $C_{o r g}$, namely negative relationships with the exception of succulents' positive effects, while soil $\mathrm{pH}$ had negative relationships with succulents but positive relationships with other life forms.

Recalling the interactions between $\mathrm{C}_{\text {org }}$, soil $\mathrm{pH}$, and depth, Jauch and Fischer (2000) observed that spread and cover by Sedum vegetation was negatively influenced by the sharp decline in $\mathrm{pH}$ two years after installation. Liesecke (1998) also observed lower species diversity on older EGRs, reporting that these systems may become dominated by one or two succulents, a single herb, and one or two moss species. Soil pH influences plant nutrient uptake because essential mineral nutrients combine with other elements at the highest and lowest $\mathrm{pH}$ values and thereby limit availability for plants. Nutrient absorption is also dependent on $\mathrm{pH}$ since an acidic substrate (less than $\mathrm{pH}$ 7) inhibits cation exchange capacity (Handreck and Black, 2010). Emilsson et al. (2007) and several German studies have shown that high plant cover is difficult to achieve without continuously adding fertiliser.

\section{Next steps}

Further analyses will attempt to determine the role of sitespecific environmental conditions to vegetation development, to explain how community-level dynamics like persistence versus colonisation proceed with time, and to characterise the physical and chemical properties of old EGR substrates. Increasing the sample size by amalgamating with other datasets may improve the power of this research; in the meantime, these results can serve as a point for discussion. More long-term monitoring of EGRs, with emphasis on vegetation and substrate development as well as hydrological function, will dramatically improve our understanding of these systems (Dunnett et al., 2008b; Rowe et al., 2012) and of urban ecosystems overall.

\section{Conclusions}

While they may not permit causal explanations, a patent theme cannot be overlooked, namely that EGRs are dynamic ecological systems that respond to multivariate factors and are subject to change over time. This research suggests that shallow EGRs tend towards substrate acidification and accumulation of soil organic content, while also becoming shallower. These effects equally influence the composition of EGR vegetation, specifically in terms of life form cover and species diversity, whereby succulent cover represents a type of climax community. Floristic diversity on the roofs surveyed ranged from simple, low diversity Sedum roofs to consistent succulent cover beneath tall meadow vegetation. Although this study is limited by sample size and lacking baseline information, its preliminary observations are substantiated by similar studies.

\section{Additional file}

Additional file 1: Full species list, including frequency and cover

abundance, for nine EGRs.

\section{Abbreviations}

$C_{\text {org: }}$ : Organic content; EGR: Extensive green roofs; TPG: Tar-paper-gravel.

\section{Competing interests}

The authors declare that this research was funded by an EU IndustryAcademia Partnership (Marie Curie IAPP), with professional and intellectual support from staff at ZinCo GmbH and from other German colleagues.

\section{Authors' contributions}

CET jointly conceived and designed the study with ND, collected and analysed data and wrote the manuscript. ND supervised the project and gave conceptual advice. Both authors read and approved the final manuscript.

\section{Acknowledgements}

Many thanks to colleagues at ZinCo GmbH, as well as other friends within the German green roof industry, and to IAPP Green Roof Team, without whose support this research would not be possible. Thanks to Dr. Oliver Pescott and Prof. Dr. Reinhard Böcker (University Hohenheim) for help in identifying mosses and graminoids. The author is indebted to harvest helpers (Trinity Pearce, Gianni Vesuviano, Claire Cannon, and Dr. Tobias Emilsson).

Received: 6 June 2013 Accepted: 1 December 2013

Published: 28 January 2014

\section{References}

Adler P (2005) Die Dachbegrünung im Wandel der Zeit. Diplom (Master's), Hochschule Nürtingen

Ansel W, Baumgarten H, Dickhaut W, Kruse E, Meier R (2011) Leitfaden Dachbegrünung für Kommunen - Nutzen - Fördermöglichkeiten Praxisbeispiele. Deutsche Bundesstiftung Umwelt, Nürtingen

Arhendt J (2007) Historische Gründächer: Ihr Entwicklungsgang bis zur Erfindung des Eisenbetons. Teil I. PhD (Dr.-Ing.). Technische Universität Berlin, Berlin

Bates AJ, Sadler JP, Mackay R (2013) Vegetation development over four years on two green roofs in the UK. Urban For Urban Green 12:98-108

Baumann N (2006) Ground-nesting birds on green roofs in Switzerland: preliminary observations. Urban Habitats 4:37-50

Berendse $F$ (1998) Effects of dominant plant species on soils during succession in nutrient-poor ecosystems. Biogeochemistry 42:73-88

Blank L, Vasl A, Levy S, Grant G, Kadas G, Dafni A, Blaustein L (2013) Directions in green roof research: a bibliometric study. Build Environ 66:23-28

Boivin MA, Lamy MP, Gosselin A, Dansereau B (2001) Effect of artificial substrate depth on freezing injury of six herbaceous perennials grown in a green roof system. Hort Technol 11:409-412 
Bornkamm R (1961) Vegetation und vegetations-entwicklung auf Kiesdäechern. Vegetatio 10:1-24

Bossler S, Suszka B (1987) Vegetation und Substrat auf Dächern in Osnabrück. Diplomarbeit, FH-Osnabrück

Bossler S, Suszka B (1988) Spontanvegetation auf Dächern in Osnabrück. Das Gartenamt 37:209-221

Braun-Blanquet J (1932) Plant sociology. In: Fuller GD, Conrad HS (eds) The study of plant communities/translated revised. McGraw-Hill, New York/London

Brenneisen S (2003) The benefits of biodiversity from green roofs: key design consequences. Greening Rooftops for Sustainable Communities. Green Roofs for Healthy Cities, Chicago, IL

Brenneisen S (2006) Space for urban wildlife: designing green roofs as habitats in Switzerland. Urban Habitats 4:27-36

Brenneisen S (2009) Ökologisches Ausgleichspotenzial von Extensiven Dachbegrünungen: Bedeutung des Ersatz-Ökotops für den Arten- und Naturschutz und die Stadtentwicklungsplanung, Liestal. Physiogeographie und Umweltwandel des Geographischen Instituts der Universität Basel, Basel

Buttschardt TK (2001) Extensive Dachbegrünungen und Naturschutz. PhD Dissertation. Universität Karlsruhe (TH), Karlsruhe (TH)

Callahan JT (1984) Long-term ecological research. Bioscience 34:363-367

CBD (2012) Cities and biodiversity outlook: action and policy. UN Secretariat of the Convention on Biological. Diversity, Montreal

Connelly M, Hodgson M (2013) Experimental investigation of the sound transmission of vegetated roofs. Appl Acoust 74:1136-1143

Cook-Patton SC, Bauerle TL (2012) Potential benefits of plant diversity on vegetated roofs: a literature review. J Environmen Manag 106:85-92

Darius F, Drepper J (1983) Ökologische Untersuchungen auf bewachsenen Kiesdaechern in West-Berlin. Diplomarbeit, TU-Berlin

Denardo JC, Jarrett AR, Manbeck HB, Beattie DJ, Berghage RD (2005) Stormwater mitigation and surface temperature reduction by green roofs. Transact Asae 48:1491-1496

Dimoudi A, Nikolopoulou M (2003) Vegetation in the urban environment: microclimatic analysis and benefits. Energy Build 35:69-76

Dunnett N, Kingsbury N (2004) Planting green roofs and living walls. Timber Press, Portland, OR

Dunnett N, Nagase A, Booth R, Grime P (2008a) Influence of vegetation composition on runoff in two simulated green roof experiments. Urban Ecosystems 11:385-398

Dunnett N, Nagase A, Hallam A (2008b) The dynamics of planted and colonising species on a green roof over six growing seasons 2001-2006: influence of substrate depth. Urban Ecosystems 11:373-384

Durhman AK, Rowe DB, Rugh CL (2007) Effect of substrate depth on initial growth, coverage, and survival of 25 succulent green roof plant taxa. Hort Sci 42:588-595

Dvorak B, Volder A (2010) Green roof vegetation for North American ecoregions: a literature review. Landsc Urban Plan 96:197-213

Ellenberg H (1986) Vegetation ecology of Central Europe. Cambridge University Press, Cambridge

Emilsson T, Rolf K (2005) Comparison of establishment methods for extensive green roofs in southern Sweden. Urban For Urban Green 3:103-111

Emilsson T, Berndtsson JC, Mattsson JE, Rolf K (2007) Effect of using conventional and controlled release fertiliser on nutrient runoff from various vegetated roof systems. Ecol Eng 29:260-271

FBB (2012) Gründachmarkt von 2008 auf 2011 um etwa 19\% gewachsen! [Online]. Fachvereinigung Bauwerksbegrünung e.V. (FBB), Saarbrücken, Germany, http://www.fbb.de/aktuelles/detailansicht/gruendachmarkt-von2008-auf-2011-um-etwa-19-gewachsen-/53/. Accessed June 72012

Fernandez-Canero R, Gonzalez-Redondo P (2010) Green roofs as a habitat for birds: a review. J Anim Vet Adv 9:2041-2052

Forschungsgesellschaft Landschaftsentwicklung Landschaftsbau (FLL) (2008) Introduction to the FLL: guidelines for the planning, construction and maintenance of green roofing. 2008 edition of the green roofing guideline. EV-FLL, Bonn

Francis RA, Lorimer J (2011) Urban reconciliation ecology: The potential of living roofs and walls. J Environ Manage 92:1429-1437

Franklin JF, Bledsoe CS, Callahan JT (1990) Contributions of the long-term ecological research-program - an expanded network of scientists, sites, and programs can provide crucial comparative analyses. Bioscience 40:509-523

Galtung J (1986) The green movement: a socio-historical exploration. Int Sociol 1:75-90
Gedge D, Kadas G (2004) Bugs, bees and spiders: green roof design for rare invertebrates. Greening Rooftops for Sustainable Communities. Green Roofs for Healthy Cities, Portland, OR

Getter KL, Rowe DB (2007) Effect of substrate depth and planting season on Sedum plug survival on green roofs. J Environ Hortic 25:95-99

Getter KL, Rowe DB (2009) Substrate depth influences Sedum plant community on a green roof. Hortscience 44:401-407

Getter KL, Rowe DB, Robertson GP, Cregg BM, Andresen JA (2009) Carbon sequestration potential of extensive green roofs. Environ Sci Technol 43:7564-7570

Grant G (2006) Green roofs and facades. UK, IHS BRE Press, Bracknell

Grant G (2012) Ecosystem services come to town: greening cities by working with nature. UK, John Wiley \& Sons, Ltd, Oxford

Grant G, Engleback L, Nicholson B (2003) English Nature Research Reports. In: Engleback E, Lia WS (eds) Green roofs: their existing status and potential for conserving biodiversity in urban areas. English Nature, Peterborough

Green Roof Systems Project (2013) Marie Curie IAPP Green Roof Systems Project. University of Sheffield, Available: http://www.green-roof-systems.co.uk. Accessed Aug 12013

Handreck K, Black N (2010) Growing media for ornamental plants and turf. Australia, University of New South Wales Press Ltd, Sydney

Hodgson JG (1990) The role of autecological accounts. In: Hillier SH, Walton DWH, Wells DW (eds) Calcareous grasslands: ecology and management. Bluntisham Books, Huntingdon

Jauch M, Fischer P (2000) Substrate im Dauertest. Deutscher Gartenbau, DeGa Spezial "GaLaBau Dachbegrünung". Verlag Eugen Ulmer, Stuttgart

Kadas G (2011) Green roofs and biodiversity: can green roofs provide habitat for invertebrates in an urban environment? LAP LAMBERT Academic Publishing, London

Kent M, Coker P (1994) Vegetation description and analysis: a practical approach. Wiley, Chichester

Köhler M, Poll PH (2010) Long-term performance of selected old Berlin greenroofs in comparison to younger extensive greenroofs in Berlin. Ecol Eng 36:722-729

Kolb W, Schwarz T (1999) Dachbegrünung: intensiv und extensiv. Eugen Ulmer, Stuttgart

Kolb W, Schwarz T, Trunk R (1983) Zur Begrünung von Kiesdächern. Zeitschrift für Vegetationstechnik 6:143-151

Krupka BW (1992) Dachbegrünung Pflanzen- und Vegetationsanwendung an Bauwerken. Verlag Eugen Ulmer, Stuttgart

Krupka BW (2006) Einschichtige Extensivbegrünungen auf Flachdächern ohne Gefälle. Dach + Grün, Berlin

Liesecke HJ (1995) Wasserrückhaltung und Abflussbeiwerte bei extensiven Dachbegrünungen. Stadt und Grün 10:683-687

Liesecke HJ (1998) Langzeitentwicklung einer extensiven Dachbegrünung Untersuchungen zum Substratverhalten und zur Vegetationsentwicklung eines 1985 ausgeführten Objektes. Stadt-und-Grün 47:428-436

Liesecke HJ (2006) Langzeitentwicklung von Substraten für die extensive Dachbegrünung. Dach + Grün 3:4-7

Likens GE (1989) Long-term studies in ecology: approaches and alternatives. Springer Verlag, New York

Lundholm J, Maclvor JS, MacDougall Z, Ranalli M (2010) Plant species and functional group combinations affect green roof ecosystem functions. PLOS ONE 5(3):e9677

Mann G (1996) Die Rolle begrünter Dächer in der Stadtökologie. Biologie in unserer Zeit 5:292-299

McGuire KL, Payne SG, Palmer MI, Gillikin CM, Keefe D, Kim SJ, Gedallovich SM, Discenza J, Rangamannar R, Koshner JA, Massmann AL, Orazi G, Essene A, Leff JW, Fierer N (2013) Digging the New York city skyline: soil fungal communities in green roofs and city parks. PLOS ONE 8(3):e58020

Mentens J, Raes D, Hermy M (2006) Green roofs as a tool for solving the rainwater runoff problem in the urbanized 21st century? Landsc Urban Plan 77:217-226

Millennium Ecosystem Assessment (2005a) Ecosystems and human well-being: biodiversity synthesis. World Resources Institute, Washington, DC

Millennium Ecosystem Assessment (2005b) Ecosystems and human well-being: synthesis. World Resources Institute, Washington, DC

Miller C (2003) Moisture management in green roofs. Greening Rooftops for Sustainable Communities. Green Roofs for Healthy Cities, Chicago, IL

Minke G, Witter G (1983) Häuser mit grünem Pelz: ein Handbuch zur Hausbegrünung. Frankfurt/Main, Fricke Verlag 
Moran A, Hunt B, Jennings G (2004) A North Carolina field study to evaluate greenroof runoff quantity, runoff quality, and plant growth. Greening Rooftops for Sustainable Communities. Green Roofs for Healthy Cities, Portland, OR

Mueller-Dombois D, Ellenberg H (1974) Aims and methods of vegetation ecology. Wiley, USA

Nagase A, Dunnett N (2010) Drought tolerance in different vegetation types for extensive green roofs: Effects of watering and diversity. Landsc Urban Plan 97:318-327

Oberndorfer E, Lundholm J, Bass B, Coffman RR, Doshi H, Dunnett N, Gaffin S, Kohler M, Liu KKY, Rowe B (2007) Green roofs as urban ecosystems: ecological structures, functions, and services. Bioscience 57:823-833

Osmundson T (1999) Roof gardens: history, design, and construction. W.W. Norton \& Company, London

Peck SW (2012) Green roof industry begins era of triple digit growth! Living Architecture Monitor. Green Roofs for Healthy Cities, Toronto

Poll PH (2008) Ökologie alter Dachbegrünungen - Ein Vergleich zwischen einfachen Jahrhundertwendedächern und komplexen Systemdächern der 80er Jahre. Freien Universität Berlin, Berlin, Diplom/Master's Diplomarbeit

Roth-Kleyer S (2002) Was Dachsubstrate leisten müssen. Jahrbuch Dachbegrünung 2002. Bundesverband Garten-Landschafts- und Sportplatzbau, Bad Honnef

Roth-Kleyer S (2006) Probleme beim Aufbringen von Substraten durch Gebläse, Teil 1. Neue Landschaft 51:27-30

Rowe D, Getter KL, Durhman AK (2012) Effect of green roof media depth on Crassulacean plant succession over seven years. Landsc Urban Plan 104:310-319

Sailor DJ (2008) A green roof model for building energy simulation programs. Energy and Buildings 40:1466-1478

Santamouris M, Pavlou C, Doukas P, Mihalakakou G, Synnefa A, Hatzibiros A, Patargias P (2007) Investigating and analysing the energy and environmental performance of an experimental green roof system installed in a nursery school building in Athens, Greece. Energy 32:1781-1788

Schrader S, Boening M (2006) Soil formation on green roofs and its contribution to urban biodiversity with emphasis on Collembolans. Pedobiologia 50:347-356

Simmons MT, Gardiner B, Windhager S, Tinsley J (2008) Green roofs are not created equal: the hydrologic and thermal performance of six different extensive green roofs and reflective and non-reflective roofs in a sub-tropical climate. Urban Ecosystems 11:339-348

Snodgrass EC, Mclntyre $L$ (2010) The green roof manual: a professional guide to design, installation and maintenance. Timber Press, Inc., Portland, OR

Snodgrass EC, Snodgrass LL (2006) Green roof plants: a resource and planting guide. OR, Timber Press, Inc, Portland

Speak AF, Rothwell JJ, Lindley SJ, Smith CL (2012) Urban particulate pollution reduction by four species of green roof vegetation in a UK city. Atmos Environ 61:283-293

Stovin V, Vesuviano G, Kasmin H (2012) The hydrological performance of a green roof test bed under UK climatic conditions. J Hydrol 414-415:148-161

Takebayashi H, Moriyama M (2007) Surface heat budget on green roof and high reflection roof for mitigation of urban heat island. Build Environ 42:2971-2979

Thuring CE, Berghage RD, Beattie DJ (2010) Green Roof Plant Responses to Different Substrate Types and Depths under Various Drought Conditions. Horttechnology 20:395-401

Tonietto R, Fant J, Ascher J, Ellis K, Larkin D (2011) A comparison of bee communities of Chicago green roofs, parks and prairies. Landsc Urban Plan 103:102-108

Uhl M, Schiedt L, Mann G, Henneberg M (2003) Langzeitstudie zum Abflussverhalten begrünter Dächer. Wasser \& Boden, Parey Buchverlag, Berlin

UNFPA (2007) State of World Population 2007: Unleashing the Potential of Urban Growth. United Nations Population Fund, USA

UNFPA (2011) The state of world population 2011. United Nations Population Fund, USA

van der Maarel E (2005) Vegetation ecology. Blackwell, Oxford

VanWoert ND, Rowe DB, Andresen JA, Rugh CL, Fernandez RT, Xiao L (2005) Green roof stormwater retention: Effects of roof surface, slope, and media depth. J Environ Qual 34:1036-1044

Vesuviano G (2013) A two-stage runoff detention model for a green roof. PhD thesis. The University of Sheffield, Sheffield
Villarreal EL, Bengtsson L (2005) Response of a Sedum green-roof to individual rain events. Ecol Eng 25:1-7

Weiler SK, Scholz-Barth K (2009) Green roof systems: a guide to the planning, design, and construction of landscapes over structure. John Wiley \& Sons, Hoboken, NJ

Williams NSG, Rayner JP, Raynor KJ (2010) Green roofs for a wide brown land: Opportunities and barriers for rooftop greening in Australia. Urban For Urban Green 9:245-251

Wong NH, Chen Y, Ong CL, Sia A (2003) Investigation of thermal benefits of rooftop garden in the tropical environment. Build Environ 38:261-270

Yio MHN, Stovin V, Werdin J, Vesuviano G (2013) Experimental analysis of green roof substrate detention characteristics. Water Sci Technol 68(7):1477-1486

ZinCo GmbH (2013) Product list, Systems and components for roof landscapes. ZinCo GmbH, Nürtingen

doi:10.1186/2192-1709-3-4

Cite this article as: Thuring and Dunnett: Vegetation composition of old extensive green roofs (from 1980s Germany). Ecological Processes 2014 3:4.

\section{Submit your manuscript to a SpringerOpen ${ }^{\odot}$ journal and benefit from:}

- Convenient online submission

- Rigorous peer review

- Immediate publication on acceptance

- Open access: articles freely available online

- High visibility within the field

- Retaining the copyright to your article

Submit your next manuscript at springeropen.com 